\title{
MANAJEMEN KURIKULUM BERBASIS INDUSTRI KREATIF PADA KOMPETENSI KEAHLIAN KRIYA KREATIF LOGAM DAN PERHIASAN SMKN 12 SURABAYA
}

\author{
Sari Vaporizki \\ Program Studi Manajemen Pendidikan Universitas Negeri Surabaya \\ Sarivaporizki214@gmail.com
}

\begin{abstract}
Abstrak: Penelitian ini dilatarbelakangi oleh masalah pengangguran yang masih didominasi oleh Iulusan Sekolah Menengah Kejuruan (SMK). Untuk mengatasi permasalahan tersebut melalui Instruksi Presiden (Inpres) Nomor 9 Tahun 2016 tentang Revitalisasi SMK, pemerintah melakukan revitalisasi pada komponen-komponen yang ada salah satunya kurikulum berbasis industri kreatif yakni kurikulum yang diselaraskan dengan kebutuhan industri. Tujuan penelitian ini untuk mendeskripsikan menelaah serta menganalisis perencanaan, pelaksanaan dan evaluasi kurikulum.Penelitian ini menggunakan pendekatan kualitatif dengan metode penelitian studi kasus. Hasil penelitian ini menunjukkan bahwa: 1) Perencanaan kurikulum berbasis industri kreatif dilakukan melalui rapat koordinasi dengan melibatkan pihak industri melalui kegiatan link and matchdan rapat sosialisasi untuk memberikan pemahaman kepada semua pihak; 2) Pelaksanaan kurikulum berbasis industri kreatif melalui pembelajaran yang berbasis kreativitas yang dilaksanakan dikelas (bengkel) dan juga diluar kelas (Prakerin). Untuk mewujudkan pelaksanaan pembelajaran yang kreatif ini maka dibutuhkan kesiapan guru dalam mengajar dengan peningkatan kompetensi guru melalui magang guru, expert dengan perusahaan serta guru melakukan percobaan terlebih dahulu sebelum menyampaikan bahan ajar kepada peserta didik. 3) Evaluasi kurikulum berbasis industri kreatif ini disetiap pembelajaran terdapat assesment dari guru terkait ketercapaian peserta didik, evaluasi di semester 1 dan 2 melalui ujian-ujian baik berupa tes lisan, tes tertulismaupun unjuk kerja dan evaluasi yang melibatkanpihak eksternal yakni industri terkait melalui Ujian Kompetensi Keahlian (UKK).
\end{abstract}

Kata Kunci: manajemen kurikulum,kurikulum berbasis industri kreatif.

Kebutuhan dan tantangan dunia kerja yang semakin kompleks untuk mempersiapkan Sumber Daya Manusia (SDM) yang berkualitas di era Revolusi Industri 4.0 ini, yang menuntut setiap tenaga pekerja untuk memiliki dan menguasai kompetensi profesional agar dapat menjadi SDM yang dapat berkompetisi didunia kerja dan industri. Tuntutan inilah yang mengharapkan pendidikan dapat melahirkan generasigenerasi bangsa yang berkarakter, inovatif, kreatif, terampil dan peka terhadap kearifan lokal disekitar.

Sekolah Menengah Kejuruan (SMK) merupakan suatu lembaga pendidikan menengah yang berorientasi untuk mempersiapkan peserta didik agar mampu terjun langsung didunia usaha dan industri setelah lulus sekolah dengan dibekali kompetensi tertentu sesuai bidangnya, akan tetapi fakta dilapangannyasaat ini untuk tingkat penyerapan di dunia kerja lulusan SMK masih belum optimal dan persentase pengangguran di Indonesia saat ini didominasi oleh lulusan SMK. Hal ini didukung berdasarkan data pada Badan Pusat Statistika (www.bps.co.iddiakses pada 25 Oktober 2018). Tingkat Pengangguran Terbuka (TPT) pada Februari 2018 sebanyak 5,13 persen turun sebanyak 0,37 persen dibanding pada Agustus 2017, meskipun tingkat pengangguran terbuka mengalami penurunan,akan tetapi mayoritas pengangguran merupakan angkatan kerja lulusan pendidikan menengah sebanyak 9,48 persen dan pengangguran terbanyak 
tersebut merupakan lulusan Sekolah Menengah Kejuruan (SMK) sebesar 11,41 persen, lalu Sekolah Menengah Atas sebesar 8,29 persen, diploma sebesar 6,88 persen dan Universitas sebesar 5,18 persen.

Solusi yang dilakukan pemerintah untuk menangani masalah tersebut, tercantum pada Instruksi Presiden (Inpres) Nomor 9 Tahun 2016 tentang Revitalisasi SMK Revitalisasi tersebut terdiri dari peningkatan akses dan mutu, inovasi pembelajaran dan inovasi kelembagaan. Melalui inpres tersebut, presiden menugaskan Kementerian Pendidikan dan Kebudayaan untuk mendesain sebuah peta jalan untuk pengembangan SMK; penyempurnaan dan penyelarasan kurikulum SMK dengan kompetensi sesuai pengguna lulusan serta meningkatkan akses sertifikasi lulusan SMK (Pracihara,2017).Salah satu program revitalisasi Sekolah Menengah Kejuruan (SMK) dalam inovasi pembelajaran yaitu Penguatan Kurikulum lokal 4 bidang unggulan potensi wilayah: kemaritiman, pertanian, pariwisata, dan industri kreatif. Sebagai salah satu potensi yang di kembangkan melalui kurikulum, industri kreatif saat ini menjadi komoditas yang diunggulkan dikarenakan melalui perkembangannya mampu membantu pembangunan ekonomi nasional. SMKN 12 Surabaya merupakan salah satu dari 125 Sekolah yang direvitalisasi karena tergolong memiliki jurusan dalam bidang industri kreatif.

Sektor industri kreatif terutama dalam bidang kerajinan sangat berpeluang besar dalam meningkatkan perekonomian negara sehingga permasalahan yang dihadapi terkait banyaknya pengangguran dapat diatasi melalui sektor industri kreatif, seperti hal nya masalah pengangguran lulusan SMK yang dijelaskan diatas dapat diatasi melalui penguatan kurikulum berbasis industri kreatif sebagai salah satu kurikulum yang diimplementasikan dalam pembelajaran sehingga dapat menghasilkan lulusan yang berkompeten dan mampu kreatif serta berinovasi. Depdiknas (2004) menyebutkan bahwa kurikulum merupakan sekumpulan rencana dan pengaturan mengenai keahlian yang ditetapkan dan metode yang digunakan untuk mencapainya yang diselaraskan dengan situasi dan kemampuan yang dimiliki (Triwiyanto, 2015)Tujuan dari kurikulum ini sendiri untuk menumbuhkan kreatifitas, kecakapan dan inovatif peserta didik dari dirinya sendiri untuk memulai menciptakan industri kecil yang berdaya saing.Berdasarkan hasil penelitian yang dilakukan oleh (Widiaty, 2013) hasil kajian memperlihatkan bahwa industri kreatif di berbagai program studi perlu menjadi program keahlian yang dikembangkan secara serius di masa kini dan masa yang akan datang, mengingat industri kreatif memiliki nilai jual yang tinggi di dalam persaingan dunia usaha sehingga mampu mengurangi tingkat pengangguran dan kemiskinan di Indonesia. Untuk mempersiapkan kurikulum yang sesuai dengan kebutuhan didunia usaha dan industri, dibutuhkan perencanaan yang matang untuk mempersiapkan segala sesuatu yang dibutuhkan untuk mewujudkan tujuan dari kurikulum berbasis industri kreatif ini. perencanaan adalah sekumpulan kegiatan yang dilakukan untuk melaju ke depan. Perencanaan ini dilakukan sebelum melaksanakan kurikulum, dengan memilih serta menentukan keputusan untuk pelaksanaan fungsi-fungsi lainnya (M. Busro \& Siskandar, 2017). Perencanaan kurikulum ini dilaksanakan dengan dua kegiatan yaitu perencanaan yang direncanakan oleh pusat dan yang direncanakan oleh sekolah. Perencanaan kurikulum berbasis industri kreatif di SMKN 12 Surabaya sebenarnya sudah dilaksanakan oleh pusat dengan adanya struktur kurikulum sampai dengan perangkat pembelajaran yang kemudian di sekolah disinkronisasikan kembali dengan kebutuhan dan tuntutan yang ada di industri melalui kegiatan link and match.

Menurut Hodge,2011:29 (Hariyati, 2018) "Review on Link and Match concept reflects condition of cooperation between Vocational High School and industry containing aspect of relevance for its implementation. Based on link and match concept between Vocational High School and industry, vocational curriculum used should be based on principle of relevance. It will be the basis for various crucial decision giving direction for the successful planning and implementation of programs in Vocational High School. Fast development in workplace requires continuous review on existing curriculum to see whether it is still relevant or not with the need of industry. 
Vocational education "fails" if the graduates are not able to meet the need and requirements of industry'. (Berdasarkan konsep link and match mencerminkan kondisi kerja sama antara SMK dan industri yang mengandung aspek relevansi untuk implementasinya. Berdasarkan konsep link and match antara Sekolah Menengah Kejuruan dan industri, kurikulum kejuruan yang digunakan harus berdasarkan pada prinsip relevansi. Ini akan menjadi dasar bagi berbagai keputusan penting yang memberikan arahan bagi keberhasilan perencanaan dan implementasi program di SMK. Pengembangan yang cepat di tempat kerja membutuhkan tinjauan terus menerus tentang kurikulum yang ada untuk melihat apakah itu masih relevan atau tidak dengan kebutuhan industri. Pendidikan kejuruan "gagal" jika lulusannya tidak mampu memenuhi kebutuhan dan persyaratan industri ). Maka dari itu link and match sangat diperlukan dalam menjamin hubungan kerjasama yang baik antara sekolah dan industri. Hal ini juga dilakukan oleh SMKN 12 Surabaya terutama Kompetensi Keahlian Kriya Kreatif Logam dan Perhiasan yang juga terus melakukan link and match dengan industri mulai dari terkait materi yang ditekankan dalam kurikulum yang digunakan oleh sekolah ini yang disesuaikan dengan kebutuhan industri sampai dengan keterserapan lulusan di industri terkait seperti yang sedang dilakukan oleh kompetensi keahlian kriya kreatif logam dan perhiasan dengan PT. Lestari Mulia Sentosa.Tahap perencanaan kurikulum berbasis industri kreatif kemudian diaktualisasikan kedalam Rencana Program Pembelajaran (RPP). Guru dalam tahap ini menyusun tujuan, bahan serta metode pembelajaran yang digunakan serta didukung oleh media dan sumber belajar yang sesuai serta instrumen evaluasi yang digunakan (Daryanto, 2013).

Sebagai bentuk pelaksanaan dari kurikulum berbasis industri kreatif, pembelajaran merupakan aktualisasi dari perencanaan yang telah dilaksanakan. Pelaksanaan kurikulum adalah penerapan program kurikulum yang telah direncanakan sebelumnya, kemudian dicoba untuk diterapkan di lapangan serta melakukan penyesuaian kondisi dan karakteristik peserta didik (Hamalik, 2007). SMKN 12
Surabaya sebagai sekolah yang menerapkan kurikulum berbasis industri kreatif juga menerapkan model pembelajaran Teaching Factory sebagai penunjang proses pembelajaran untuk menghasilkan peserta didik yang berkompeten dengan mengacu pada perangkat pembelajaran yang terdiri dari rancangan produk, job sheet, jadwal blok, serta dokumen lainnya. Terdapat beberapa kegiatan utama dalam implementasi kurikulum sebagai berikut: Tahap persiapan, pelaksanaan dan evalusi pembelajaran ( muhammad dkk Busro, 2017). Faktor yang paling utama yang dapat mempengaruhi pelaksanaan kurikulum berasal dari guru. Sebaik apapun fasilitas dan sarana pendidikan jika tidak didukung oleh kemampuan profesional guru maka pelaksanaan kurikulum tidak akan berhasil dan tidak dapat mencapai tujuan yang telah ditetapkan sebelumnya (Hamalik, 2011: 239).

Untuk menilai dan mengetahui bagaimana keadaan proses pelaksanaan kurikulum yang berguna untuk perbaikan pada pelaksanaan kurikulum selanjutnya maka perlu adanya evaluasi. Evaluasi kurikulum bertujuan memantau tingkat ketercapaian tujuan pendidikan yang ingin diwujudkan melalui kurikulum yang terkait (Hamid, 2012: 202).Evaluasi ini dilakukan dengan menilai seberapa besar hasil pembelajaran, tingkat ketercapaian dari program yang telah direncanakan, sertahasil dari kurikulum itu sendiri (Busro dan Siskandar, 2017:23). Evaluasi dilakukan secara terbuka, bertahap, dan berkesinambungan. Dalam pelaksanaannya evaluasi kurikulum dapat diukur dengan menggunakan instrumen pengukuran oleh pendidik, terdiri dari: 1) Tes standar, 2) Tes buatan guru, 3) Sampel hasil karya, 4) Tes lisan, 5) observasi sistematis, 6) Wawancara, 7) Kuesioner, 8)Daftar cek dan skala penilaian, 9) kalkulator anekdotal serta 10) Sosiogram dan pelaporan (Hamalik, 2011:180).

Menurut Hamalik (2011:191), dalam mengevaluasi suatu pelaksanaan kurikulum, seoarang evaluator perlu untuk mempertimbangkan hal penting berikut yakni: evaluasi formatif (digunakan untuk memperbaiki program), serta evaluasi sumatif digunakan untuk mengambil sebuah 
keputusan untuk melanjutkan atau menghentikan sebuah program. Kurikulum sebenarnya digunakan untuk memperbaiki substansi kurikulum, aturan implementasi, metode implementasi serta pengaruh implementasi terhadap pembelajaran dan perilaku peserta didik.

SMKN 12 Surabaya merupakan salah satu sekolah yang melakukan revitalisasi SMK dalam sektor pengembangan yaitu Industri Kreatif. Revitalisasi ini dilaksanakan sejak 2016, sekolah ini termasuk bagian 125 SMK terevitalisasi lebih awal yang akan didorong untuk melakukan perubahan dan penyelarasan kurikulum yang mengacu pada dunia usaha dan industri. Revitalisasi yang dilakukan SMKN 12 Surabaya ini dalam sektor seni pertunjukkan, seni rupa, dan kriya kerajinan. Empat program studi industri kreatif SMKN 12 Surabaya yang akan dilakukan revitalisasi itu antara lain Animasi, Kriya logam, Kriya Tekstil dan Seni Tari. Kriya logam merupakan satu-satunya kompetensi keahlian SMK yang ada di Provinsi Jawa Timur.

Berdasarkan uraian latar belakang yang telah di paparkan diatas, fokus penelitian ini mengenai Manajemen Kurikulum Berbasis Industri Kreatif padaKompetensi Keahlian Kriya Logam SMKN 12 Surabaya. Dari fokus tersebut dapat diuraikan menjadi beberapa subfokus, yaitu sebagai berikut:

1. Perencanaan kurikulum berbasis industri kreatif padaKompetensi Keahlian Kriya Kreatif Logam dan PerhiasanSMKN 12 Surabaya.

2. Pelaksanaan kurikulum berbasis industri kreatif padaKompetensi Keahlian Kriya Kreatif Logam dan PerhiasanSMKN 12 Surabaya.

3. Evaluasi yang dilakukan dalam pelaksanaan kurikulum berbasis industri kreatif pada Kompetensi Keahlian Kriya Kreatif Logam dan Perhiasan SMKN 12 Surabaya.

\section{METODE}

Pendekatan penelitian yang digunakan dalam penelitian ini adalah pendekatan kualitatif dan menggunakan rancangan penelitian studi kasus. Yin (2011:4) juga menjelaskan bahwa sebagai suatu upaya untuk penelitian, studi kasus ini dapat memberikan nilai plus pada pengetahuan kita secara unik mengenai fenomena individual, politik dan sosial. Kasus yang diangkat dalam penelitian ini yakni manejemen kurikulum berbasis industri kreatif pada kompetensi keahlian kriya kreatif logam dan perhiasan di SMKN 12 Surabaya yang berlokasi di Jl. Siwalankerto Permai No. 1 RT. 4 RW. 6.Subjek dalam penelitian ini terdiri dari kepala sekolah, waka bidang kurikulum, ketua kompetensi keahlian kriya kreatif logam dan perhiasan, ketua bengkel, guru produktif, peserta didik. Kehadiran peneliti disekolah dalam rangka untuk melakukan kunjungan secara intesif ke sekolah guna melakukan pengamatan serta pengumpulan data yang relevan dengan fokus penelitian ini.Peneliti dalam penelitian ini berperan sebagai pengamat penuh yang kehadiran peneliti dijelaskan secara terbuka kepada subjek penelitian, sehingga seluruh warga sekolah mengetahui peneliti hadir di tengah-tengah sekolah dengan status sebagai peneliti (Moleong, 2014).Pelaksanaan observasi akan berlangsung selama kurang lebih dua bulan dengan frekuensi kehadiran peneliti di SMKN 12 Surabaya dilakukan setiap hari sesuai jadwal sekolah.Teknik pengumpulan data merupakan tahapan-tahapan yang paling utama dalam penelitian, dikarenakan tujuan dilakukannya penelitian itu sendiri untuk mengumpulkan dan memperoleh data (Sugiyono, 2008).Pengumpulan data pada penelitian ini dilakukan dengan menggunakan wawancara, observasi dan studi dokumentasi. Uji keabsahan data yang dilakukan dengan menggunakan beberapa teknik sebagai berikutkredibilitas(credibility) melalui triangulasi teknik, triangulasi sumber dan membercheck ,transferabilitas (transferability), dependabilitas

(dependability), dankonfirmabilitas

(confirmability). Penelitian ini juga menggunakan teknik analisis data melalui Kondensasi Data (Data Condensation), Penyajian Data (Data Display) dan Verifikasi Data

\section{HASIL DAN PEMBAHASAN \\ Perencanaan Kurikulum Berbasis Industri Kreatif di Kompetensi Keahlian Kriya Kreatif Logam dan Perhiasan}

Salah satu tahap yang dapat mempengaruhi dalam tercapaianya keberhasilan pembelajaran disekolah yakni perencanaan kurikulum. Berdasarkanhasil 
temuan peneliti di SMKN 12 Surabaya khususnya di Kompetensi Keahlian Kriya Kreatif Logam dan Perhiasan ini sudah menggunakan kurikulum berbasis industri kreatif yang merupakan kurikulum yang sesuai dengan potensi daerah yang ada dilingkungan sekitar sekolah yakni industri kreatif. Perkembangan bidang industri kreatif baik pada masa kini maupun di masa depan perlu dikoordinasi oleh dunia pendidikan dalam bentuk pengembangan dan perbaikan kurikulum sesuai dengan kebutuhan dunia usaha dan industri, hal ini sejalan dengan yang dikemukakan oleh (Matthew \& Ede, 2010)bahwa untuk menjaga relevansi antara program pendidikan kejuruan dengan dunia kerja maka: curriculum must be reviewed, enriched, and update regularly inline with changes that are taking place in the industries (kurikulum harus ditinjau, diperkaya, dan diperbarui secara teratur sejalan dengan perubahan yang terjadi di industri).

Sejak tahun 2016 sekolah ini menjadi salah satu sekolah yang direvitalisasi oleh pemerintah pusat. Berdasarkan temuan yang didapat oleh peneliti kegiatan perencanaan kurikulum berbasis industri kreatif ini dilaksanakan pada tingkat pusat dan dilaksanakan oleh sekolah, untuk perencanaan pada tingkat pusat mulai dari struktur kurikulum sampai dengan perangkat pembelajaran lainnya yang kemudian diterima oleh sekolah dan disinkronisasikan dengan kebutuhan industri terkait melalui rapat koordinasi (Hamalik, 2007). Kemudian akan dilakukan rapat sosialisasi untuk memberikan pemahaman kepada seluruh pihak terkait kurikulum berbasis industri kreatif ini.

Dengan ditetapkannya kurikulum berbasis industri kreatif maka Kepala Sekolah beserta pihak-pihak terkait yang tergabung dalam tim pengembang kurikulum mengatur dan merencanakan tujuan, isi, dan bahan pelajaran, serta cara yang digunakan untuk mencapai tujuan pendidikan tertentu. Tujuan tersebut meliputi tujuan pendidikan nasional, kesesuaian dengan kekhasan, kondisi dan potensi daerah, satuan pendidikan dan peserta didik (UU No. 20 Tahun 2003). Selain itu tim pengembang kurikulum merumuskan visi, misi, dan tujuan sekolah dengan menyesuaikan berbasis industri kreatif dikarenakan perencanaan sendiri merupakan menetapkan suatu tujuan untuk bertindak sebelum tindakan tersebut diimplementasikan (Daryanto \& Abdullah, 2013)

Guru dalam tahap ini menyusun tujuan, bahan serta metode pembelajaran yang digunakan serta didukung oleh media dan sumber belajar yang sesuai serta instrumen evaluasi yang digunakan untuk mendukung pembelajaran yang kreatif (Daryanto \& Abdullah, 2013). Tujuan diadakannya perencanaan ini yakni untuk menentukan apa yang ingin dicapai dari pelaksanaan kurikulum ini. Selain itu salah satu fungsi yang diharapkan dari kurikulum berbasis industri kreatif ini yakni fungsi persiapan, berdasarkan hasil temuan peneliti kurikulum berbasis industri kreatif ini diharapkan dapat membantu peserta didik untuk siap kerja sesuai dengan tujuan SMK yakni mencetak lulusan yang siap kerja (Hamalik, 2007)

Konsep pendidikan industri kreatif bagi peserta didik untuk menciptakan daya kreatif, inovasi serta mandiri seseorang agar mampu menjadi manusia yang berkompetensi pada bidangnya sehingga dapat menyalurkan kemampuannya tersebut kedalam dunia kerja yang sesungguhnya, mengacu pada konsep pendidikan tersebut Kompetensi Keahlian Kriya Kreatif Logam dan Perhiasan merumuskan visi jurusan yaitu Menjadi lembaga vokasi generasi muda yang berwawasan dunia kerja dalam bidang kriya logam dengan misi yakni Menumbuhkan semangat Apresiatif, Kreatif, dan Inovatif dalam berkarya serta menanamkan budaya siap "KERJA" (Kreatif, Efisien, Rajin, Jujur, Amanah) yang unggul.

Dengan demikian Kompetensi Keahlian Kriya Kreatif Logam dan Perhiasan SMKN 12 Surabaya merencanakan kurikulum berbasis industri kreatif berdasarkan ketentuan revitalisasi SMK. Melalui visi dan misi itulah diharapkan Kompetensi Keahlian Kriya Kreatif Logam dan Perhiasan SMKN 12 Surabaya dapat mencapai tujuan khusus pendidikan SMK yang sebagaimana tercantum pada UU No. 20 Tahun 2003 tentang Sisdiknas yakni mempersiapkan peserta didik agar menjadi manusia produktif, mampu bekerja mandiri, mengisi lowongan pekerjaan yang tersedia di dunia kerja sebagai tenaga kerja tingkat menengah, sesuai dengan paket keahlian yang diikutinya. 
Untuk mewujudkan hal tersebut berdasarkan hasil temuan peneliti, Kompetensi Keahlian Kriya Kreatif Logam SMKN 12 Surabaya sering melakukan komunikasi yang baik dengan industri terkait kurikulum yang akan dijalankan sekolah melalui kegiatan Link and Match baik mengundang industri ke sekolah atau berkunjung ke industri secara langsung, melalui guru magang maupun kegiatan lainnya yang dapat memberikan hubungan timbal balik antar sekolah maupun industri sehingga kurikulum berbasis industri kreatif ini dapat diimplementasikan dengan baik. Selain itu untuk mempersiapkan bahan ajar guru biasanya akan melakukan uji coba atau eksperimen individu sebelum bahan ajar tersebut di sampaikan ke peserta didik.

Kompetensi Keahlian Kriya Kreatif Logam dan Perhiasan SMKN 12 Surabaya sendiri mengacu pada Struktur Kurikulum yang tercantum dalam Permendikbud No. 70 Tahun 2013 tentang Kerangka Dasar dan Struktur Kurikulum SMK/MAK sebagai acuan dalam proses pembelajaran yang akan dilaksanakan disekolah pada periode waktu tertentu dengan menggunakan metode tertentu serta media pembelajaran tertentu yang disesuaikan dengan jenis pembelajaran yang akan dilakukan. Melalui struktur kurikulum ini, sekolah akan lebih mudah dalam menyusun matapelajaran yang akan dilaksanakan dalam satu tahun pelajaran.

Berdasarkan pemaparan tesebut, menurut peneliti keseluruhan dariproses perencanaan kurikulum berbasis industri kreatif di Kompetensi Keahlian Kriya Kreatif Logam dan Perhiasan sudah sesuai dengan persyaratan yang diberikan dalam merencanakan kurikulum berbasis industri kreatif. Namun, hasil temuan penelitian terkait proses perencanaan kurikulum berbasis industri kreatif di Kompetensi Keahlian Kriya Kreatif Logam dan Perhiasan juga masih variatif mengingat kebutuhan dan perkembangan di dunia industri masih bersifat dinamis dan secara terus menerus memerlukan pembenahan terkait perencanaan kurikulum yang harus disesuaikan dengan perkembangan yang ada di industri sehingga dalam pengimplentasiannya sesuai dengan kebutuhan industri. Dalam hal ini SMKN 12 Surabaya harus terus meningkatkan strategi dalam pembelajaran melalui kegiatan perencanaan ini sehingga peserta didik dapat memiliki kompetensi yang sesuai dengan kebutuhan industri dan siap kerja.

\section{Pelaksanaan Kurikulum Berbasis Industri Kreatif di Kompetensi Keahlian Kriya Kreatif Logam dan Perhiasan}

Pelaksanaan kurikulum merupakan suatuproses pengaktualisasian perencanaan yang telah dilakukan sebelumnya. Halini berguna untuk menunjang keberhasilan terhadap segala sesuatu yang telah direncanakan. Hal ini sependapat dengan yang disampaikan oleh (M. Busro \& Siskandar, 2017) yang menyatakan bahwa pelaksanaan kurikulum adalah penerapan program kurikulum yang telah direncanakan sebelumnya, kemudian dicoba untuk diterapkan di lapangan serta melakukan penyesuaian kondisi dan karakteristik peserta didik. Berdasarkan temuan peneliti, kurikulum berbasis industri kreatif ini diterapkan untuk menumbuhkan kreatifitas pada peserta didik sehingga dapat memiliki kompetensi terkait bidangnya masing-masing. Hal ini dapat membantu untuk mewujudkan tujuan SMK yakni meningkatnya keterserapan peserta didik didunia kerja secara maksimal.

Menurut (M. Busro \& Siskandar, 2017) implementasi kurikulum ini merupakan kegiatan pembelajaran yang dilaksanakan melalui beberapa tahap meliputi: tahap persiapan, tahap pelaksanaan pembelajaran serta tahap penutupan. Tahap tersebut juga dilakukan oleh tenaga pendidik yang ada di kompetensi keahlian kriya kreatif logam dan perhiasan dalam mengimplementasikan pembelajaran. Berdasarkan observasi yang dilakukan peneliti, guru produktif akan melakukan uji coba atau eksperimen terlebih dahulu sebelum menyampaikan materi tersebut kepada peserta didik hal ini dilakukan sebagai langkah awal persiapan yang dilakukan oleh guru agar materi atau bahan ajar yang diberikan kepada peserta didik benar-benar matang disampaikan oleh guru dan diterima dengan baik oleh peserta didik.

Setelah itu tahap pelaksanaan pembelajaran yang dilakukan oleh guru dan peserta didik didalam kelas (bengkel) dan tahap terakhir yakni penutupan yakni segala aktivitas yang dilakukan setelah proses pembelajaran selesai.Selain itu, terdapat kegiatan utama lain yang diungkapkan oleh 
(Hamalik, 2007) antara lain tahap pengembangan kurikulum, tahap pelaksanaan pembelajaran serta tahap evaluasi proses. Kegiatan utama ini juga dilaksanakan oleh sekolah ini berdasarkan hasil studi dokumentasi yang dilakukan oleh peneliti terdapat dokumen berupa program tahunan, dan program semester yang disusun guru sebagai hasil breakdown dari kurikulum yang telah direncanakan sebelumnya. Kemudian tahap pelaksanaan pembelajaran yakni pelaksanaan pembelajaran yang dilakukan baik dikelas (bengkel) maupun diluar kelas (industri). Tahap terakhir yakni evaluasi proses yang dilakukan guru selama proses pembelajaran berlangsung, baik penilaian formatif maupun penilaian sumatif terkait proses penciptaan karya atau produk oleh peserta didik di bengkel maupun di industri.

Faktor yang mendukung pelaksanaan kurikulum ini di kompetensi keahlian kriya kreatif logam dan perhiasan yakni guru, seperti hasil temuan peneliti di lapangan bahwa faktor utama yang mendukung pelaksanaan kurikulum ini adalah guru yang profesional karena sebaik-baiknya kurikulum jika guru sebagai fasilitator tidak berkompeten maka kurikulum ini tidak akan bisa menghasilkan lulusan yang siap kerja. Hal ini sependapat dengan yang dijelaskan (Hamalik, 2007) yang menyatakan bahwa faktor yang paling utama yang dapat mempengaruhi pelaksanaan kurikulum berasal dari guru. Sebaik apapun fasilitas dan sarana pendidikan jika tidak didukung oleh kemampuan profesional guru maka pelaksanaan kurikulum tidak akan berhasil dan tidak dapat mencapai tujuan yang telah ditetapkan sebelumnya.

Untuk mengetahui proses pelaksanaan kurikulum berbasis industri kreatif ini pada Kompetensi Keahlian Kriya Logam dapat dilihat melalui struktur kurikulum SMK berdasarkan Peraturan Dirjen DikDasMen Kemendikbud Nomor, 07/D.D5/KK/2018 tentang Struktur Kurikulum SMK/MAK. Pelaksanaan kurikulum yang dilakukan oleh kompetensi keahlian kriya kreatif logam ini juga memerhatikan prinsip-prinsip yang dapat menunjang tercapainya keberhasilan pelaksanaan kurikulum salah satunya yakni pendekatan dan kemitraan yang dilakukan sekolah dengan industri terkait untuk membahas sinkronisasi terkait materi dalam kurikulum yang perlu ditekankan dalam proses pembelajaran agar dapat memenuhi kebutuhan industri saat ini. Selain itu, berdasarkan hasil temuanterdapat prinsip lain yang diperhatikan dalam implementasi kurikulum disekolah ini yakni relevansi yakni kesesuaian dengan kebutuhan didunia kerja dan industri, fleksibilitas yakni pembelajaran yang selalu mengikuti perubahan yang terjadi di industri saat ini, praktis yakni dalam proses pembelajaran penggunaan sarana dan prasarana sudah disesuaikan dengan yang ada di industri terkait. Hal ini sependapat dengan yang disampaikan dalam PSMK yang menyebutkan bahwa prinsip yang perlu diperhatikan dalam implementasi kurikulum yakni relevansi, fleksibilitas, kontinuitas, praktis dan efektivitas.

Pelaksanaan kurikulum di kompetensi keahlian kriya kreatif logam dan perhiasan ini dapat ditunjang melalui strategi pembelajaran seperti Link and Match dengan industri, Teaching Factory yang baru saja diterapkan di jurusan ini, kemudian learning by doing yakni peserta didik langsung mempraktekkan materi yang diberikan oleh guru terkait mata pelajaran tertentu. Hal tersebut sejalan dengan yang disampaikan oleh (Muhamad, 2017) yang menyatakan bahwa Strategi pembelajaran yang dapat dilakukan untuk menunjang dalam pelaksanaan kurikulum industri di SMK sebagai berikut : Link And Match, Demand-Driven, Dual-Based Program, Teaching Factory, Learning By Doing danprogram lainnya. Hal ini didukung oleh hasil temuan yang diperoleh peneliti terkait pembelajaran yang dilaksanakan di kompetensi keahlian kriya kreatif logam dan perhiasan yakni pembelajaran yang berbasis kreativitas, hal tersebut dapat diwujudkan melalui startegi pembelajaran learning by doing.

Hal tersebut juga sejalan dengan hasil penelitian yang dilakukan oleh Rabendra (Yudistira, Ramadhani, Indrayana, \& Hadi, 2016)menyatakan kreatifitas disini yang berarti suatu pembelajaran yang didalamnya melakukan kegiatan kreatif yaitu learning by doing. Pelaksanaan kurikulum di kompetensi keahlian kriya kreatif logam dan perhiasan ini juga menemui beberapa kendala yang dihadapi selama proses pembelajaran ini berlangsung seperti terkait peralatan 
bengkel sekolah yang masih belum bisa mengikuti perkembangan teknologi di industri seperti software metrik untuk perhiasan dan alat inject di pengelasan, kemudian ketersediaan alat dengan jumlah peserta didik yang tidak seimbang.

\section{Evaluasi Kurikulum Berbasis Industri Kreatif di Kompetensi Keahlian Kriya Kreatif Logam dan Perhiasan}

Evaluasi merupakan suatu kegiatan yang penting dalam menilai ketercapaian dari pelaksanaan pembelajaran yang telah dilakukan. Hal ini sejalan dengan yang disampaikan oleh (Hamalik, 2007) yang menyatakan bahwa evaluasi adalah proses untuk menilai kinerja pelaksanaan suatu kurikulum. Pelaksanaan evalausi yang dilakukan di kompetensi keahlian kriya kreatif logam dan perhiasan ini melakukan evaluasi dengan menggunakan instrument pengukuran yang dibuat oleh guru yang dilaksanakan selama pembelajaran ini berlangsung. Pembelajaran di kompetensi keahlian kriya kreatif logam dan perhiasan ini mengacu pada hasil jadi yakni sebuah produk maka evaluasi yang dilakukan guru yakni selama peserta didik dalam proses menciptakan sebuah produk mulai dari proses awal sampai hasil akhir selalu dilakukan assesment untuk melihat ketercapaian peserta didik pada kompetensi tertentu.

Kemudian terdapat evaluasi di setiap semesternya melalui ujian-ujianbaik berupa tes lisan, tes tertulis maupun unjuk kerja,serta juga ada evaluasi yang melibatkan pihak eksternal yakni industri terkait melalui Ujian Kompetensi Keahlian (UKK). Pelaksanaan evaluasi yang dilakukan di kompetensi keahlian kriya kreatif logam dan perhiasan ini memperhatikan indikator penilaian yang sesuai dengan kompetensi peserta didik untuk mencapai tujuan pembelajaran industri kreatif yakni aspek kognitif, aspek psikomotorik serta aspek afektif. Hal tersebut didukung dengan hasil temuanpeneliti terkait Kriteria Penilaian Ujian Kompetensi Keahlian (UKK).

Indikator tersebut sejalan dengan hasil penelitian yang dilakukan oleh (Yudistira et al., 2016). Evaluasi yang dilakukan dikompetensi keahlian kriya kreatif logam dan perhiasan menggunakan evaluasi sumatif dan formatif (Hamalik, 2007) hal ini berdasarkan hasil temuan yang didapat peneliti bahwa evaluasi yang dilakukan selain untuk melihat ketercapaian peserta didik pada kompetensi tertentu, evaluasi ini juga dilakukan untuk menentukan apakah materi pembelajaran dapat dilanjutkan pada materi selanjutnya ataukah perlu adanya pengulangan pada materi sebelumnya. Hal ini juga didukung berdasarkan hasil temuan yang didapat peneliti terkait daftar nilai praktek/skill evaluasi ini dilakukan pada setiap tugas yang diberikan baik tugas sehari-hari, tugas proyek maupun tugas produk.

Berhubungan dengan evaluasi formatif sekolah ini melakukan rencana tindak lanjut setelah melaksanakan evaluasi ini antara lain rencana tindak lanjut terkait masalah yang berasal dari guru dan rencana tindak lanjut yang dilakukan terkait masalah yang berasal dari peserta didik. Untuk rencana tindak lanjut terkait masalah guru, sekolah akan memberangkatkan guru untuk magang ke industri terkait kompetensi yang ingin ditingkatkan, sedangkan rencana tindak lanjut terkait masalah peserta didik, sekolah menyarankan peserta didik untuk melakukan pembelajaran lebih dalam ke TUK/ industri terkait dengan kompetensi yang akan di tingkatkan, selain itu guru akan memberikan materi baru yang tingkatannya lebih tinggi jika peserta didik sudah dapat menyelesaikan materi sebelumnya tujuannya untuk memperbaiki program yang telah dilaksanakan.

Tujuan diadakannya evaluasi ini yakni untuk menentukan apakah pembelajaran yang selama ini dilaksanakan di kompetensi tersebut sudah dapat mencapai target atau dengan kata lain peserta didik dapat memiliki kompetensi yang dibutuhkan di industri dan sesuai dengan yang diharapkan dari perencanaan kurikulum sebelumnya. Hal tersebut sependapat dengan yang disampaikan oleh Oemar Hamalik (2008:250) yang menyebutkan bahwa evaluasi pelaksanaan kurikulum bertujuan untuk melihat proses pelaksanaan yang sedang berjalan sebagai fungsi kontrol apakah pelaksanaan tersebut telah sesuai dengan rencana dan sebagai fungsi perbaikan jika terdapat kekurangan. Selain itu evaluasi juga bertujuan untuk melihat hasil akhir yang dicapai, hasil ini merujuk pada kriteria waktu dan hasil yang ingin 
dicapai kemudian dibandingkan dengan fase perencanaan (M. Busro \& Siskandar, 2017)

Maka dari itu evaluasi perlu dilakukan pada waktu-waktu tertentu dan secara berkala dengan memerhatikan instrumen yang digunakan yang disesuaikan dengan jenis evaluasi yang akan dilakukan oleh guru. Pada kompetensi keahlian kriya kreatif logam dilakukan evaluasi diakhir pembelajaran pada tingkat kelas 12 yakni adanya tugas akhir dengan membuat satu set perhiasan diantaranya yakni kalung, cincin, gelang, anting-anting dll yang kemudian akan dipamerkan pada pameran tahunan di luar sekolah. Evaluasi dari tugas akhir itu juga memberikan pengaruh atas nilai yang akan diperoleh peserta didik setelah lulus nanti ditambah dengan nilai tugas praktek lainnya.

Pelaksanaan evaluasi ini juga membutuhkan dukungan dari peserta didik itu sendiri sebagai objek evaluasi ini, kendala yang sering dihadapi guru dalam evaluasi pada matapelajaran produktif ini yakni peserta didik berasal dari input yang kurang dalam kompetensi akademik dikarenakan proses seleksi yang kurang memerhatikan kompetensi dibidang ini sebagai syarat utama untuk dapat diterima di kompetensi kehalian kriya kreatif logam ini maka dari itu hal ini dapat mempengaruhi proses pembelajaran yang dilakukan oleh peserta didik sehingga proses evaluasi terhadap ketercapaian dalam pembelajaran pun tidak mudah.

Berdasarkan hasil temuan yang diperoleh oleh peneliti bahwa evaluasi dilakukan dengan melihat keterserapan peserta didik pada dunia kerja atau industri karena tujuan dari kurikulum berbasis industri kreatif ini sendiri yakni menyiapkan peserta didik siap kerja maupun menjadi wirausaha pada bidang industri kreatif terkait. Untuk mewujudkan lulusan yang berkompeten sesuai kebutuhan industri maka evaluasi di kompetensi keahlian kriya kreatif logam dan perhiasan ini juga melibatkan pihak luar yakni industri untuk ikut mengevaluasi ketercapaian kompetensi peserta didik melalui kegiatan ujian kompetensi keahlian (UKK) dengan melibatkan pihak industri yaitu PT. Star Ligomas dan PT. Eka Silver dan Gold Industri sebagai penguji eksternal .
Berdasarkan pemaparan diatas menurut peneliti proses evaluasi yang dilakukan oleh kompetensi keahlian kriya kreatif logam dan perhiasan sudah sangat baik dan maksimal untuk mencapai tujuan dari diterapkannya kurikulum berbasis industri kreatif ini dengan tidak hanya melibatkan guru sebagai evaluator internal akan tetapi juga melibatkan industri sebagai evaluator eksternal demi tercapianya tujuan evaluasi yang diharapkan oleh sekolah ini. Selain itu dengan melibatkan industri sebagai evaluator eksternal, sekolah dapat mengetahui lebih dalam terhadap ketercapaian yang sudah diraih oleh peserta didik melalui sudut pandang industri sebagai pemakai lulusan kompetensi ini nantinya.

\section{KESIMPULAN}

Berdasarkan hasil dan pembahasan diatas, maka dapat ditarik kesimpulan sebagai berikut:

1. Perencanaan kurikulum berbasis industri kreatif di Kompetensi Keahlian Kriya Kreatif Logam dan Perhiasan ini sesuai dengan regulasi dari pemerintah pusat, namun sekolah tetap melakukan sinkronisasi dengan kebutuhan di industri. Kemudian disosialisasikan kepada stakeholder yang bersangkutan untuk memberikan pemahaman terkait kurikulum berbasis industri kreatif ini, sehingga perencanaan kurikulum berbasis industri kreatif di kompetensi keahlian ini dapat terencana dengan baik.

2. Pelaksanaan kurikulum berbasis industri kreatif di Kompetensi Keahlian Kriya Kreatif Logam dan Perhiasan inimelalui pembelajaran berbasis kreativitas yang dilaksanakan di kelas (bengkel) dan juga diluar kelas (Prakerin) di 25 industri terkait. Melalui pelaksanaan pembelajaran berbasis kreativitas, peserta didik pada kompetensi keahlian ini dapat memiliki keahlian yang dibutuhkan di dunia kerja dan industri sehingga keterserapan lulusan untuk bekerja dapat secara maksimal tersalurkan.

3. Evaluasi kurikulum berbasis industri kreatif di Kompetensi Keahlian Kriya Kreatif Logam dan Perhiasan ini melalui kegiatan assessment untuk melihat ketercapaian peserta didik, kemudian evaluasi di setiap semester melalui ujian- 
ujian baik berupa tes lisan, tes tertulis maupun unjuk kerja dan evaluasi yang dilakukan oleh pihak industri melalui ujian kompetensi keahlian (UKK).Melalui evaluasi yang dilakukan secara maksimal dan komprehensif pada setiap komponen pembelajaran tersebut maka hal ini dapat mewujudkan tujuan kurikulum untuk dapat menghasilkan peserta didik yang berkompeten.

\section{SARAN}

Berdasarkan hasil dan pembahasan serta kesimpulan diatas, maka yang dapat peneliti sarankan yaitu:

1. KepalaSMKN 12 Surabaya diharapkan dapat lebih memaksimalkan proses perencanaan yang dilakukan dengan didukung sumber daya pendukung yang baik mulai dari SDM yang profesional sampai dengan peralatan sekolah yang lebih menunjang.Untuk mendukung proses pembelajaran sehingga dapat meningkatkan kualitas pembelajaran yang berbasis kreativitas seperti yang diharapkan sekolah saat ini.

2. Ketua kompetensi keahlian kriya kreatif logam dan perhiasan, diharapkan dapat terus meningkatkan komunikasi yang baik dengan industri terkait penyerapan alumni di dunia kerja dan industri

3. Guru produktif, diharapkan dapat meningkatkan wawasan terkait kurikulum ini sehingga mulai dari proses perencanaan, pelaksanaan dan evaluasi dapat dilaksanakan dengan baik dan tujuan dari kurikulum ini dapat tercapai sesuai harapan.

4. Peneliti lain, diharapkan dapat memperluas fokus penelitian yang akan dilakukan sehingga kajian yang akan dihasilkan lebih variatif dari penelitian ini dan dapat digunakan sebagai bahan referensi lain terkait manajemen kurikulum.

\section{DAFTAR RUJUKAN}

Busro, muhammad dkk. (2017).

Perencanaan dan Pengembangan

Kurikulum. yogyakarta: media akademi.

Busro, M., \& Siskandar. (2017).

Perencanaan dan Pengembangan

Kurikulum. Yogyakarta: media akademi.
Daryanto, A. (2013). Pengantar IImu Manajemen dan Komunikasi. Jakarta: PT. Prestasi Pustakarya.

Daryanto, \& Abdullah. (2013). Pengantar IImu Manajemen dankomunikasi. Jakarta: Prestasi Pustakarya.

Hamalik, O. (2007). Dasar-dasar pengembangan kurikulum. Bandung: PT. Remaja Rosdakarya.

Hariyati, N. (2018). Using Social Exchange Theory To Describe Cooperation Partnership Strategy Between Vocational High School With Business/Industrial World. International Journal of Civil Engineering and Technology (IJCIET), 9(8), 668-679.

Matthew, O. A., \& Ede, E. O. (2010). Integration of new technological innovations in automobiles into the curriculum for Nigerian technical college programmes. International Journal of Vocational and Technical Education, 2(5), 89-94.

Moleong, J. (2014). Lexy, Metodologi Penelitian kualitatif, Penerbit PT. Remaja Rosdakarya Bandung.

Muhamad, H. (2017). Strategi Implementasi Revitalisasi SMK (10 Langkah Revitalisasi SMK). Jakarta: Direktorat Pembinaan Sekolah Menengah Kejuruan.

Sugiyono, P. D. (2008). Metode penelitian kuantitatif dan kualitatif dan R\&D. Bandung (ID): Alfabeta.

Triwiyanto, T. (2015). Manajemen Kurikulum dan Pembelajaran. Jakarta: Bumi Aksara.

Widiaty, I. (2013). Relevansi kurikulum SMK berbasis industri kreatif dengan metode extrapolation and the econometric approach. Innovation of Vocational Technology Education, 9(1).

Yudistira, R., Ramadhani, N., Indrayana, S. D., \& Hadi, W. (2016). Studi Kurikulum SMK Berbasis Industri Kreatif di Indonesia Timur. Imajinasi: Jurnal Seni, 10(2), 133-142. 